\title{
Remuneration Committees' Gender Composition as a Determinant of Executive Board Compensation Structure
}

\author{
Job Borrenbergs $^{1}$, Rui Vieira ${ }^{1,2}$, Georgios Georgakopoulos ${ }^{1}$ \\ ${ }^{1}$ Amsterdam, Business School, University of Amsterdam, Amsterdam, The Netherlands \\ ${ }^{2}$ I. E. Business School, I. E. University, Madrid, Spain \\ Correspondence: Rui Vieira, I. E. Business School, I. E. University, Calle Pedro de Valdivia, 21, 28006 Madrid, \\ Spain. E-mail: rui.vieira@ie.edu \\ Received: November 22, 2016 \\ Accepted: January 13, 2017 \\ Online Published: January 18, 2017 \\ doi:10.5539/ibr.v10n2p135 \\ URL: http://dx.doi.org/10.5539/ibr.v10n2p135
}

\begin{abstract}
This paper investigates the relationship between the gender composition of firms' remuneration committees and the relative weight of variable monetary compensation in these firms' top executives' compensation packages. Previous archival research into executive compensation has mainly relied on agency theory, managerial power theory and tournament models to construct its theoretical frameworks. However, both psychological and corporate governance-related research concerning gender differences in, for instance, risk- and inequality-aversion, suggest that the gender variable should be included in the academic debate on executive compensation.

Controlling for size, industry, and corporate governance variables, this paper uses simple least squares analysis to regress measures of the relative weight of variable compensation against measures of female presence in remuneration committees, in a sample of 25806 fiscal year/executive combinations. This regression is repeated in a multilevel model that controls for firm fixed effects in a sample of 9048 fiscal year / executive combinations. The results indicate that a female presence in the remuneration committee is negatively associated with the relative weight of the annual bonus in top executives' compensation contracts.
\end{abstract}

Keywords: corporate governance, executive compensation, gender, psychological research, remuneration committees

\section{Introduction}

This paper examines whether the gender composition of a firm's remuneration committee influences the relationship between fixed and variable monetary compensation for top executives. In recent years, the compensation of managers and executives has received much attention in the popular press as well as in academic research, particularly in the corporate governance and in the management accounting fields. The performance-contingent part of top executives' reward packages has caused much debate within governments, unions and the investment community. Several theories have been put forward to explain the variance in pay practices across firms and industries, such as agency theory, managerial power theory, and tournament models. However, these theories have not yet been able to provide definitive evidence on the determinants of executive compensation (Lambert, Larcker, \& Rajan, 1993). The corporate governance literature has examined the role of women on boards of directors and how gender diversity on corporate board influences corporate governance outcomes that in turn impact performance (Nielsen \& Huse, 2010; Rose, 2007; Terjesen, Sealy, \& Singh, 2009). However, to the best of our knowledge, this is the first paper that investigates the relationship between the gender composition of firms' remuneration committees and the relative weight of variable monetary compensation in these firms' top executives' compensation packages. This paper contributes to the literature by exploring the effect of gender, which has not been considered extensively in corporate governance and management accounting research before.

In most large firms, executive compensation contracts are determined by a committee of the board of directors called the remuneration committee (or compensation committee). This study investigates the effect of a female presence in firms' remuneration committees on the relative weight of performance-contingent pay for top executives. It uses ordinary least squares analysis to test for this effect in a large sample of US and Canadian firms. The results indicate that a female presence in the remuneration committee has a negative association with the 
relative weight of the annual bonus. The remainder of this paper is organized as follows: the next section contains a literature review; section three develops the hypothesis; the data and sample selection are discussed in section four; section five explains the empirical methodology; and section six presents and discusses the empirical results.

\section{Rewards Management}

For enterprises in which ownership and management are separated, the problem of determining appropriate rewards for managers has long been recognized. In the words of Adam Smith (1904: 30):

'[T] he wages of labour are everywhere understood to be, what they usually are, when the labourer is one person, and the owner of the stock which employs him another.

What are the common wages of labour, depends everywhere upon the contract usually made between those two parties, whose interests are by no means the same'.

In more recent times, the debate on incentives for corporate managers has been dominated by agency theory, which deals with the design of reward systems as a way to align the interest of managers with those of owners (Jensen \& Meckling, 1976).

In a basic agency relationship, a principal (owner) employs an agent (manager) to perform actions that provide pay-offs for the principal. These actions are generally assumed to be unobservable to the principle. In order to motivate the agent to perform the actions that optimize the principle's utility, the principle designs a contract that makes the agent's compensation dependent on observable performance-related outcomes. Holström (1979) shows that any measure of performance that reveals information about the agent's effort level should be included in this compensation contract. However, no set of performance measures will be perfectly correlated with the agent's effort, because uncontrollable environmental effects will always influence the outcomes to a certain extent. Therefore, performance-contingent compensation contracts shift risk from the principal to the risk-averse agent, who will demand to be paid a risk-premium.

Adopting an agency theory perspective, Lazear (1998) constructs a model to determine the optimal compensation contract between a principal and an agent. In this model, the contract that would create the highest value for both sides is one in which the agent pays the principal a fixed amount of money to be allowed to perform the job, after which the agent holds the full residual claim on the company's profits.

Agency models of compensation have been subjected to intensive empirical testing. For instance, Jensen and Murphy (1990) demonstrate that the link between pay and performance in US firms is very weak. Similar results had been found before, and have been found since (e.g. Taussig \& Baker, 1925; Tosi, Werner, Katz, \& Gomez-Mejia, 2000). Numerous arguments have been put forward to explain the absence of a direct empirical relationship between firm performance and executive compensation in general. For instance, the desirability of linking pay to performance depends on factors like the agent's level of risk-aversion, the clarity and directness of the relationship between effort and performance results, and the monitoring mechanism (Gomez-Mejia \& Wiseman, 1997). Research from an analogous perspective has focused on how the relative weight of incentive pay varies with relevant parameters - for instance risk, in the form of performance measurement noise (e.g. Aggarwal \& Samwick, 1999; Ittner, Larcker, \& Rajan, 1997). However, empirical evidence does not clearly indicate that compensation contracts are designed to optimally trade off risk against incentive models like Lazear's (Prendergast, 1999).

Some authors propose to combine the insights of agency theory with other theoretical perspectives (Eisenhardt, 1989). For instance, the managerial power approach investigates the influence that top executives can exert over the corporate board members who determine their compensation package. Focusing on the behaviour of remuneration committees, Daily, Johnson, Ellstrand, and Dalton (1998) investigate whether the presence of committee members who are affiliated with the incumbent CEO or who have been appointed during the tenure of the incumbent CEO (i.e. 'interdependent' directors) is related to the structure of CEO compensation. Directors are labelled 'affiliated' if they are also managers of the firm or have other personal or professional relations with the CEO. These authors find no support for a relationship between the structure of CEO compensation and the presence of affiliated or interdependent committee members. Conversely, the results of Newman and Mozes (1999) do indicate that the presence of CEO-affiliates in the remuneration committee biases CEO compensation at the expense of the share-holders.

Another theoretical perspective has been proposed by Rosen (1986). He views the working of organizational hierarchies as a sequential elimination tournament in which employees compete with each other to move to the next stage. That is, high performing employees are promoted to higher managerial levels on the basis of their performance relative to other employees. Because the chance of being promoted for any individual employee is small, and they are assumed to be effort-averse, the benefits of being promoted must be substantial in order to 
motivate employees to exert effort and compete in the tournament. In other words: employees make a trade-off between the cost of effort and the benefits of being promoted and being able to compete in the higher stages. These benefits include the potential to earn the rewards that belong to all higher organizational levels for which the employee can still compete. However, as the employee moves further up the hierarchy, the value of these potential benefits decreases because there are fewer future levels for which he or she can compete. To compensate for this decreasing value, firms should offer higher rewards at each subsequent hierarchical level. This argument is particularly important at the final round of the tournament, because the employees competing in this round have no future stages in their career horizons. This implies that the difference in compensation between winning and losing the final round should be greater than in previous rounds. In other words: the CEO should earn substantially more than his or her direct subordinates.

Lambert et al. (1993) evaluate the ability for agency, managerial power and tournament theories to explain the variance in manager's compensation. Using a major consulting firm's confidential survey data on compensation for four distinct organizational levels, they find that the use of performance-contingent compensation can best be explained by a combination of these three theories. In this study, the mean incremental explanatory power is $5.80 \%$ for the tournament model, $6.76 \%$ for the managerial power model and $0.71 \%$ for the agency model. Thus, although Lambert et al. (1993) provide an important contribution to the literature on organizational incentives, their paper still fails to explain a substantial part of the variance in compensation practices.

In reaction to the continuing failure to find definitive evidence on the determinants of top executive pay, some scholars have suggested that research in this area leans too heavily on archival data (Tosi et al., 2000). Following this argument, several authors have attempted to look inside the 'black box' of the executive remuneration process, by using a more qualitative research approach to study the behaviour and dynamics of remuneration committees (e.g. Main, Jackson, Pymm, \& Wright, 2008). However, it is not evident that the possibilities of using archival data to study the determinants of executive board compensation have been exhausted. For instance, Young and Buchholtz (2002) use demographic variables to explain the variance in CEO compensation. These authors find a relationship between the extent to which CEO pay is tied to performance, and the demographic dissimilarity between the CEO and members of the remuneration committee.

The gender composition of remuneration committees may also have an effect on the executive board compensation package. The effects of gender-differences have received little attention in management accounting and corporate governance research, therefore more research in this field is advocated (Terjesen et al., 2009). As will be argued below, the variable 'gender' should not be omitted from research into organizational practices. Given the considerable body of theoretical and empirical work on gender in organizations, an investigation of the possible effects of this variable on management accounting practices could contribute to the debate outlined above.

\section{Hypotheses}

In business studies, research that focuses on gender can be divided into two (intertwining) streams: either it takes a critical, feminist approach - attempting, for instance, to 'deconstruct' accepted values in organizations in order to uncover hidden mechanisms of gender-discrimination (Mills \& Simmons, 1995); or it uses gender simply as an independent demographic variable to explain variations in organizational behaviour (for instance: gender is the most widely studied demographic variable in business ethics research: Robin and Babin, 1997). As far as we are aware, the latter approach has not firmly established itself in the management accounting academic tradition (respectively: Baxter \& Chua, 2003; Luft \& Shields, 2003). The critical approach to gender in management accounting has received attention in special issues of Accounting, Organizations and Society (1987: 1), and Accounting, Auditing and Accountability Journal (1992: 3 and 2008:4). In the absence of a clearly defined body of related management accounting literature and corporate governance on which to build, this study has a somewhat exploratory nature. Building on gender-related literature in other academic disciplines, two conflicting views on the possible effects of the gender composition of remuneration committees on top executive compensation are identified.

The first of these views relates to agency theory by considering the aspect of risk-aversion. In an overview of experimental research on gender differences in economic preferences, Croson and Gneezy (2009) find that risk-preference has been shown to differ between women and men, with women being more risk-averse than men. A major explanatory factor for this difference is the affective reaction to risk. Men and women differ in their emotional reaction to uncertain situations. Because emotions affect the evaluation of outcomes as well as the evaluation of probabilities, different emotional reactions result in differences in risk taking. Also, men have generally been found to be more confident than women. Men may therefore have a different perception of the probability distribution underlying a given risk. Finally, men tend to view risky situations as challenges, as 
opposed to threats, which lead to increased risk tolerance (Croson \& Gneezy, 2009).

Directly relating to incentive pay, Dohmen and Falk (2011) find that variable pay-schemes attract men more than women. Next to these experimental findings, several archival studies indicate that female executives receive a larger portion of their total compensation in the form of salary, as opposed to incentive pay (e.g. Albanesi \& Olivetti, 2006; Chauvin \& Ash, 1994).

Also, social scientists have investigated gender differences in leadership styles. In a meta-analysis of academic research in this area, Eagly and Johnson (1990) find that women tend to adopt a more democratic and participative management style. Female managers display more skilful interpersonal behaviour in terms of understanding others' feelings and intentions, and allow for more collaborative decision-making in order to overcome an attitudinal bias against female leaders. The Croson and Gneezy (2009) study cited above also suggests that women are more inequality averse in dictator games (i.e. games in which a participant has to divide a certain amount of money between herself and another participant.) The authors argue that this result is due to women's stronger sensitivity to the decision-making context. For instance, they find that women's decisions in dictator games are sensitive to the gender and home state of their counterpart while men's are not.

In addition, Bell (2005) indicates that although there is an unexplained gender gap in the compensation-levels of top executives (i.e. women earn less than men), this gap is smaller in firms that are led by women.

Taking into account the higher risk-aversion of women, their personal preference for salary as opposed to bonuses, the tendency of female CEOs to reduce the pay gap for their employees, and the democratic, participative female management style, one could argue that women in remuneration committees may exhibit a tendency to limit the proportion of incentive pay in the compensation contracts for their firms' top executives. Importantly, findings of gender differences in inequality-aversion may suggest that female directors in remuneration committees may tend to reduce inequality in executive compensation. In other words: a female presence in the remuneration committee may be negatively related to the relative weight of performance-contingent compensation in executive compensation packages.

Interestingly, demography-related literature in the field of corporate governance may suggest a contrasting expectation. The Young and Buchholtz's study cited above is based on the idea that individuals make more favourable decisions about other individuals who are demographically similar to themselves. Assuming CEOs are both risk averse and predominantly male, a female presence in the remuneration committee could be expected to result in a compensation package that is (according to agency theory) less favourable for the CEO, or in other words: more tied up with performance.

Recently, it has also been suggested that more demographically diverse boards (i.e. boards that include women) are better in monitoring management. It seems that more diverse boards are more likely to hold management directly accountable for firm performance. For instance, Adams and Ferreira (2009) find that CEO turnover is more sensitive to stock price development in firms with relatively more women on the board. Their study follows up on the results of Carter, Simkins, and Simpson (2003), who find that board diversity has a positive relationship with financial performance for Fortune 1000 firms. The authors partly explain these results by arguing that board diversity leads to greater board independence - and therefore to better corporate governance. Again, agency theory suggests that better corporate governance should imply a greater emphasis on pay for performance in top executives' compensation packages. This line of reasoning implies that the presence of female remuneration committee members may have a positive impact on the relative weight of performance-related pay in executive board members' compensation packages.

In the absence of well-developed theory on gender in management accounting, this study is of an exploratory nature. For this reason, it makes use of non-directional tests for the effect of the gender composition of remuneration committees on the relationship between fixed and variable monetary compensation for top executives. The null-hypothesis is formulated as follows:

H0: The presence of female remuneration committee members has no effect on the relative weight of performance-related pay in executive board members' compensation packages.

\section{Sample and Sources of Data}

To investigate the effect of a female presence in remuneration committees on the relative weight of variable compensation in executive board members' compensation packages, our analysis focuses on publicly traded US and Canadian firms. For these firms, executive compensation and accounting data for 2001 through 2006 were collected from the COMPUSTAT database. The reason we examined the 2001-2006 period is to isolate any effects from the financial crises that took hold in North America in 2007. 
In addition, data on remuneration committee characteristics for the firms in the sample were taken from the RiskMetrics Directors Legacy database. For each fiscal year the data on individual executives were matched with, on the one hand, data concerning the remuneration committee that determined the individual executive's compensation package in that year, and on the other hand, data on the firm's size and performance in that year. Twenty-one directors who received practically all of their compensation in the form of an annual bonus or stock options were regarded as outliers and excluded from the sample. This process leaves 25806 fiscal year/executive combinations with a complete set of data items. Table 1 provides descriptive statistics for the firms and remuneration committees in the sample. For this table, the fiscal year/executive combinations have been aggregated into firm-years.

Table 1. Descriptive Statistics for Firm Years

\begin{tabular}{lccc}
\hline \multicolumn{1}{c}{ Variable } & $\mathrm{N}$ & Mean & Standard deviation \\
\hline Total revenue of the firm (\$ million) & 4894 & 6933 & 18351 \\
Return On Assets of the firm (percentage) & 4894 & 0.137 & 0.044 \\
Number of remuneration committee members & 4894 & 3.809 & 1.039 \\
Number of female remuneration committee members & 4894 & 0.469 & 0.629 \\
Dummy 'independence of remuneration committee' & 4894 & 0.773 & 0.419 \\
(1= completely independent, 0 = otherwise) & 4894 & 61.236 & 4.988 \\
\hline
\end{tabular}

The average size (total revenue) of the firms in the sample is $\$ 6.93$ billion. The average return on assets is $13.7 \%$. Remuneration committees have on average 3.81 members, of whom on average 0.47 are female. $77.3 \%$ of remuneration committees are classified as completely independent. The mean age of the remuneration committee is 61.24 years on average.

Table 2 provides descriptive statistics for the fiscal year / executive combinations. The average executive manager receives $\$ 450010$ in salary and $\$ 477320$ in cash bonus annually. Other variable compensation, in the form of restricted stock grants, long-term incentive plan compensation and the fair value of option awards, amounts to $\$ 1815059$ for the average executive. 6.5\% of executives are female.

Table 2. Descriptive Statistics for Fiscal Year / Executive Combinations

\begin{tabular}{|c|c|c|c|}
\hline Variable & $\mathrm{N}$ & Mean & Standard deviation \\
\hline Salary (\$) & 25806 & 450010 & 279366 \\
\hline Annual bonus $(\$)$ & 25806 & 477320 & 1084190 \\
\hline $\begin{array}{l}\text { Other variable compensation (option awards, stock grants and } \\
\text { long-term incentive plans; } \$ \text { ) }\end{array}$ & 25806 & 1815059 & 3741002 \\
\hline Dummy 'executive's gender' $(1=$ female, $0=$ male $)$ & 25806 & 0.065 & 0.246 \\
\hline
\end{tabular}

Table 3 provides a breakdown of the percentage of women in remuneration committees per industry. For almost all industries, the percentage of women in remuneration committees is at most $24 \%$ in the vast majority of firm years. Remuneration committees with a percentage of females between $25-49 \%$ are generally reported in about $20-30 \%$ of firm-years across all industries. Remuneration committees with a percentage of females of more than $50 \%$ are reported in less than 5\% of firm-years across all industries. The only exception to this rule seems to be the wholesale and retail trade industry (one-digit SIC $=5$ ), where slightly higher percentages of females in remuneration committees occur.

Table 3. Industry Breakdown of the Percentage of Females in the Remuneration Committee per Firm per Year

\begin{tabular}{|c|c|c|c|c|c|c|}
\hline \multirow[b]{2}{*}{$\begin{array}{l}\text { 1-digit } \\
\text { SIC }\end{array}$} & \multirow[b]{2}{*}{ Industry description } & \multicolumn{5}{|c|}{ Percentage of women in the remuneration committee } \\
\hline & & $\begin{array}{c}0-24 \% \\
\quad \# \text { of } \\
\text { firm-years }\end{array}$ & $\begin{array}{c}25-49 \% \\
\quad \# \text { of } \\
\text { firm-years }\end{array}$ & $\begin{array}{c}50-74 \% \\
\quad \# \text { of } \\
\text { firm-years }\end{array}$ & $\begin{array}{c}75-99 \% \\
\quad \# \text { of } \\
\text { firm-years }\end{array}$ & $\begin{array}{c}100 \% \\
\# \text { of } \\
\text { firm-years }\end{array}$ \\
\hline 1 & Mining and construction & 220 & 58 & 3 & 0 & 0 \\
\hline 2 & $\begin{array}{l}\text { Food, apparel, paper and } \\
\text { chemical }\end{array}$ & 570 & 283 & 34 & 1 & 2 \\
\hline 3 & $\begin{array}{l}\text { Rubber, leather, stone, metal } \\
\text { and electronic }\end{array}$ & 953 & 336 & 11 & 0 & 1 \\
\hline 4 & $\begin{array}{l}\text { Transportation } \\
\text { communications }\end{array}$ & 469 & 163 & 13 & 0 & 0 \\
\hline 5 & Wholesale and retail trade & 267 & 229 & 48 & 1 & 0 \\
\hline 6 & Financial services & 514 & 133 & 24 & 3 & 1 \\
\hline 7 & $\begin{array}{l}\text { Travel, entertainment, computer } \\
\text { services }\end{array}$ & 285 & 121 & 14 & 0 & 0 \\
\hline 8 & Other services & 97 & 36 & 4 & 0 & 0 \\
\hline & Total & 3375 & 1359 & 151 & 5 & 4 \\
\hline
\end{tabular}


Figure 1 presents a summary of the data in table 3 in a graphical format. Refer to table 3 for the industry descriptions corresponding to the one-digit SIC-codes

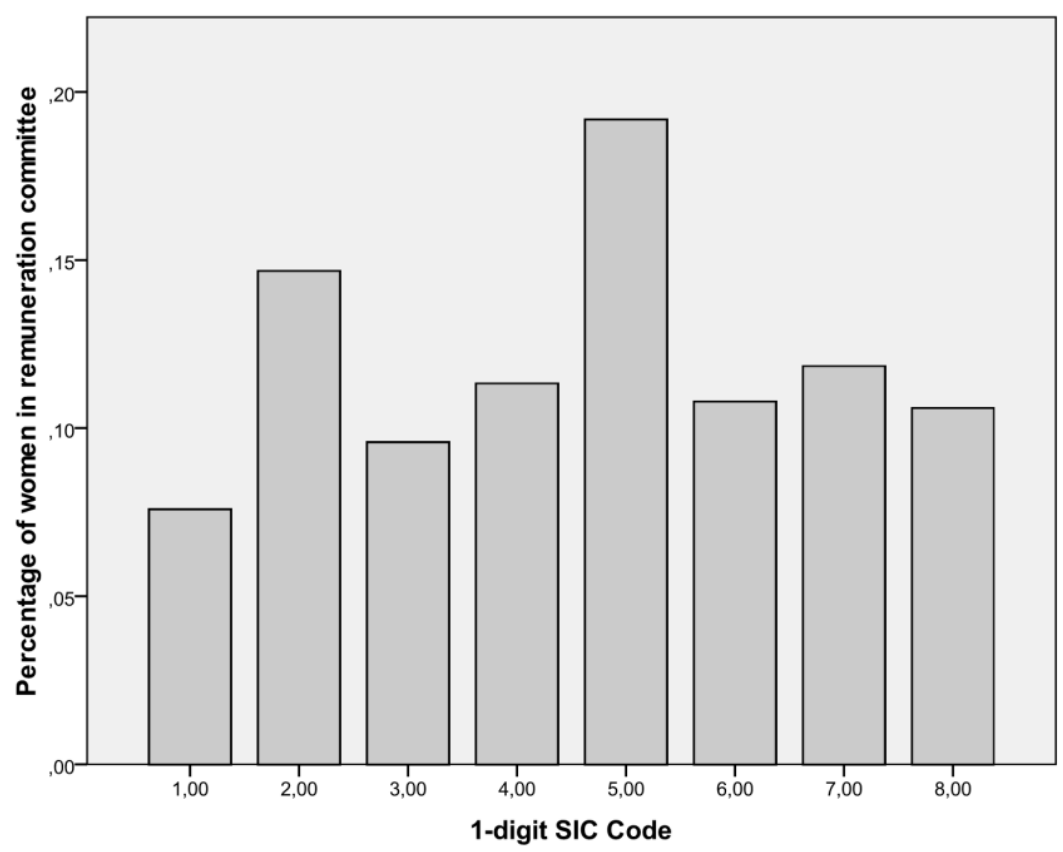

Figure 1. Industry Breakdown of the Average Percentage of Females in the Remuneration Committee

\section{Method}

The impact of female presence in remuneration committees on the relative weight of variable versus fixed pay is examined using ordinary least squares analysis and multilevel model analysis. For the ordinary least squares analysis, measures of the relative weight of variable compensation in executives' total compensation package are regressed against measures of female presence in the remuneration committees that determined the executives' compensation, as follows:

$$
\text { Relative weight of variable pay }=\alpha 0+\beta 1 \text { Female Presence_ } i+\Sigma \beta X i+\varepsilon
$$

where $x$ is a vector of control variables.

To prevent the dependent variable from being bound between 0 and 1 , measures of variable compensation divided by total compensation are avoided. Instead, the measures of the relative weight of variable pay are: annual bonus divided by salary and total variable compensation divided by salary (where total variable compensation consists of annual bonus, restricted stock grants, long-term incentive plan compensation and the fair value of options contracts).

The independent variable is the percentage of women in the remuneration committee that determined the executives' compensation package. Based on previous research (e.g. Daily et al. 1998), the following control variables are included: firm size (natural logarithm of total revenues), industry-average variable compensation (based on 2-digit SIC codes) and firm performance (measured by Return On Assets). The literature review indicates that female executives might prefer fixed pay to variable pay (Dohmen \& Falk, 2011). For that reason a dummy variable was introduced to control for the executives' gender. Adams and Ferreira (2009) suggest that the structure of compensation packages may be related to aspects of board diversity and effectiveness other than gender. For instance, large boards are generally believed to be less effective than smaller boards (Larcker, Richardson, \& Tuna, 2007). As outlined above, less effective corporate governance may be associated with a smaller emphasis on pay for performance in executive compensation packages. The same reasoning can also be applied to boards consisting of relatively older and less independent directors. For these reasons, the models also control for remuneration committee size, average age and independence (measured by a dummy variable coded 1 if the remuneration committee is completely independent and 0 if at least one member of the remuneration committee is classified in the RiskMetrics database as either 'employee' or 'linked'). 
The regression models assume that the independent and control variables are not correlated with each other. To check for multicollinearity, the Pearson correlation coefficients for the independent and control variables were calculated for the ordinary least squares regression with bonus divided by salary as dependent variable. They are presented in table 4 . None of the coefficients points towards a problematic level of correlation.

Table 4. Correlations

\begin{tabular}{|c|c|c|c|c|c|c|c|c|}
\hline & (1) & (2) & (3) & (4) & (5) & (6) & (7) & $(8)$ \\
\hline (1) Dummy for executive's gender & 1 & & & & & & & \\
\hline (2) Mean age of remuneration committee & -.006 & 1 & & & & & & \\
\hline $\begin{array}{l}\text { (3) Number of remuneration committee } \\
\text { members }\end{array}$ & -.006 & .023 & 1 & & & & & \\
\hline $\begin{array}{l}\text { (4) Percentage of women in the remuneration } \\
\text { committee }\end{array}$ & .062 & -.183 & .054 & 1 & & & & \\
\hline $\begin{array}{l}\text { (5) Dummy for remuneration committee } \\
\text { independence }\end{array}$ & .009 & .051 & -.071 & .050 & 1 & & & \\
\hline (6) $(\log )$ Total Revenue & -.006 & .100 & .206 & .190 & .067 & 1 & & \\
\hline (7) ROA compared to industry average & .013 & -.018 & .019 & .016 & .017 & .024 & 1 & \\
\hline $\begin{array}{l}\text { (8) Industry average for bonus divided by } \\
\text { salary }\end{array}$ & -.009 & -.026 & -.036 & -.067 & -.001 & -.046 & -.001 & 1 \\
\hline
\end{tabular}

Because the data in this study consist of fiscal year/executive combinations, they contain multiple observations per firm. Firms may differ in ways that are not captured by the control variables in an ordinary least squares model. Specifically, omitted variables may exist that affect both the choices in determining top executive compensation and the decision to appoint female directors. An example of such an omitted variable may be 'corporate culture'. To control for this effect, a multilevel model is used, which allows the intercept of the regression equation to vary across firms. This model can be described as follows:

$$
\text { Relative weight of variable pay }=(\alpha 0+u 0 j)+\beta 1 \text { Female Presence_ij }+\Sigma \beta x i j+\varepsilon i j
$$

Where $j$ indicates the firm level. This model essentially requires that changes in independent variables (rather than their base-levels) be associated with changes in the dependent variable. It is equivalent to including dummy variables to identify individual firms. For this analysis, only those firms are included for which data from 2001 through 2006 are available. This selection leaves a sample of 9,048 fiscal year/executive combinations.

\section{Empirical Results and Discussion}

This section contains the empirical results of the investigation into the relationship between the relative amount of variable compensation for executives, and the presence of women in the remuneration committee. Tables 5 and 6 present the results of the ordinary least squares analyses, the dependent variables being respectively 'annual bonus divided by salary' (table 5 ) and 'total variable compensation divided by salary' (table 6 ).

Table 5. Results of the Ordinary Least Squares Analysis with Annual Bonus Divided by Salary as Dependent Variable

\begin{tabular}{|c|c|c|c|c|}
\hline \multicolumn{5}{|c|}{ Parameter estimates } \\
\hline Variable & $\begin{array}{l}\text { Unstandardized } \beta \\
\text { Coefficient }\end{array}$ & $\begin{array}{c}\text { Standard } \\
\text { error }\end{array}$ & t-value & Significance \\
\hline (Constant) & -1.861 & 0.160 & -11.659 & 0.000 \\
\hline (log)Total revenue & 0.274 & 0.008 & 33.532 & 0.000 \\
\hline Return on assets compared to industry average & 0.952 & 0.167 & 5.688 & 0.000 \\
\hline Number of remuneration committee members & 0.066 & 0.012 & 5.767 & 0.000 \\
\hline $\begin{array}{l}\text { Dummy for remuneration committee } \\
\text { independence }\end{array}$ & 0.027 & 0.028 & -0.955 & 0.340 \\
\hline Mean age of remuneration committee & -0.005 & 0.002 & -2.013 & 0.042 \\
\hline Dummy for executive's gender & -0.147 & 0.048 & -3.088 & 0.002 \\
\hline $\begin{array}{l}\text { Industry average for 'annual bonus divided by } \\
\text { salary' }\end{array}$ & 0.759 & 0.015 & 49.417 & 0.000 \\
\hline $\begin{array}{l}\text { Percentage of women in the remuneration } \\
\text { committee }\end{array}$ & -0.284 & 0.075 & -3.795 & 0.000 \\
\hline
\end{tabular}

Adjusted R-square for this model is 0.124 . The value of the F-statistic is 459.580 . 
Table 6. Results of the Ordinary Least Squares Analysis with Total Variable Compensation Divided by Salary as Dependent Variable

\begin{tabular}{|c|c|c|c|c|}
\hline \multicolumn{5}{|c|}{ Parameter estimates } \\
\hline Variable & $\begin{array}{c}\text { Unstandardized } \beta \\
\text { Coefficient }\end{array}$ & $\begin{array}{c}\text { Standard } \\
\text { error }\end{array}$ & t-value & Significance \\
\hline (Constant) & -3.578 & 0.734 & -4.878 & 0.000 \\
\hline (log)Total revenue & 1.066 & 0.037 & 28.586 & 0.000 \\
\hline Return on assets compared to industry average & 5.226 & 0.762 & 6.856 & 0.000 \\
\hline Number of remuneration committee members & -0.135 & 0.052 & -2.584 & 0.010 \\
\hline $\begin{array}{l}\text { Dummy for remuneration committee } \\
\text { independence }\end{array}$ & 0.104 & 0.129 & 0.808 & 0.419 \\
\hline Mean age of remuneration committee & -0.063 & 0.011 & -5.671 & 0.000 \\
\hline Dummy for executive's gender & -0.698 & 0.217 & -3.225 & 0.001 \\
\hline $\begin{array}{l}\text { Industry average for 'total variable } \\
\text { compensation divided by salary'. }\end{array}$ & 0.950 & 0.035 & 27.384 & 0.000 \\
\hline $\begin{array}{l}\text { Percentage of women in the remuneration } \\
\text { committee }\end{array}$ & -0.730 & 0.340 & -2.145 & 0.032 \\
\hline
\end{tabular}

Adjusted R-square for this model is 0.064 . The value of the F-statistic is 220.406

Tables 7 and 8 present the results of the multilevel model analyses, the dependent variables being respectively 'annual bonus divided by salary' (table 7) and 'total variable compensation divided by salary' (table 8 ). With regard to the sample of 9048 fiscal year/executive combinations that include data from 2001 through 2006, it appears that the multilevel models achieve a better fit than the ordinary least squares models. While the multilevel models remove 1 degree of freedom, they reduce $\chi^{2}$ respectively by 5474.475 (when bonus divided by salary is the dependent variable), and 2264.319 (when total variable compensation divided by salary is the dependent variable). A critical value for the chi-square statistic with 1 degree of freedom is $6.63(\mathrm{p}<0.01)$. In addition, the relationships described by the models show significant variance in intercepts across firms (bonus divided by salary: $\operatorname{var}(\mathrm{u} 0 j)=1.902$; total variable compensation divided by salary: $\operatorname{var}(\mathrm{u} 0 j)=9.125)$.

Table 7. Results of the Multilevel Model Analysis with Annual Bonus Divided by Salary as Dependent Variable

\begin{tabular}{|c|c|c|c|c|c|}
\hline \multicolumn{6}{|c|}{ Parameter estimates } \\
\hline Variable & Estimate & $\begin{array}{l}\text { Standard } \\
\text { error }\end{array}$ & $\begin{array}{l}\text { Degrees of } \\
\text { freedom }\end{array}$ & t-value & Significance \\
\hline (Constant) & 0.314 & 0.523 & 2072.410 & 0.600 & 0.548 \\
\hline (log)Total revenue & 0.279 & 0.045 & 898.814 & 6.165 & 0.000 \\
\hline $\begin{array}{l}\text { Return on assets compared to industry } \\
\text { average }\end{array}$ & 1.828 & 0.408 & 7490.288 & 4.485 & 0.000 \\
\hline $\begin{array}{l}\text { Number of remuneration committee } \\
\text { members }\end{array}$ & 0.067 & 0.018 & 8905.118 & 3.634 & 0.000 \\
\hline $\begin{array}{l}\text { Dummy for remuneration committee } \\
\text { independence }\end{array}$ & 0.079 & 0.050 & 9041.804 & 1.595 & 0.111 \\
\hline Mean age of remuneration committee & -0.046 & 0.006 & 8930.495 & -8.003 & 0.000 \\
\hline Dummy for executive's gender & -0.183 & 0.061 & 8838.905 & -2.996 & 0.003 \\
\hline $\begin{array}{l}\text { Industry average for 'annual bonus divided } \\
\text { by salary' }\end{array}$ & 0.923 & 0.114 & 284.315 & 8.097 & 0.000 \\
\hline $\begin{array}{l}\text { Percentage of women in the remuneration } \\
\text { committee }\end{array}$ & -0.319 & 0.145 & 8970.995 & -2.195 & 0.028 \\
\hline
\end{tabular}

Tables 5 and 6 (with dependent variables respectively 'bonus divided by salary' and 'total variable compensation divided by salary') indicate that the estimated beta-coefficient for the independent variable 'Percentage of women in the remuneration committee' is statistically significant in a negative direction. Tables 7 and 8 show that the multilevel model only confirms this finding when bonus divided by salary is the dependent variable. The relationship between the percentage of women in the remuneration committee and total variable compensation divided by salary is not significant in the multilevel model.

These results imply that H0 (The presence of female remuneration committee members has no effect on the relative weight of performance-related pay in executive board members' compensation packages) should be rejected. Specifically, the presence of women in remuneration committees has a negative effect on the relative weight of the annual bonus in top executives' compensation packages. The models do not provide conclusive evidence with regard to the relative weight of total variable compensation in executives' compensation packages. Judging from the chi-square statistic, the multilevel models seem to achieve a better fit than the ordinary least squares models. 
Table 8. Results of the Multilevel Model Analysis with Total Variable Compensation Divided by Salary as Dependent Variable

\begin{tabular}{|c|c|c|c|c|c|}
\hline \multicolumn{6}{|c|}{ Parameter estimates } \\
\hline Variable & Estimate & $\begin{array}{l}\text { Standard } \\
\text { error }\end{array}$ & $\begin{array}{l}\text { Degrees of } \\
\text { freedom }\end{array}$ & t-value & significance \\
\hline (Constant) & -9.255 & 1.865 & 899.689 & -4.963 & 0.000 \\
\hline (log)Total revenue & 1.257 & 0.120 & 494.999 & 10.472 & 0.000 \\
\hline Return on assets compared to industry average & 8.424 & 1.356 & 3978.194 & 6.211 & 0.000 \\
\hline Number of remuneration committee members & 0.018 & 0.064 & 7872.914 & 0.276 & 0.783 \\
\hline $\begin{array}{l}\text { Dummy for remuneration committee } \\
\text { independence }\end{array}$ & 0.183 & 0.175 & 8705.561 & 1.047 & 0.295 \\
\hline Mean age of remuneration committee & -0.009 & 0.020 & 7503.446 & -0.460 & 0.645 \\
\hline Dummy for executive's gender & -0.938 & 0.219 & 8930.738 & -4.289 & 0.000 \\
\hline $\begin{array}{l}\text { Industry average for 'total variable } \\
\text { compensation divided by salary' }\end{array}$ & 0.813 & 0.225 & 284.633 & 3.614 & 0.000 \\
\hline $\begin{array}{l}\text { Percentage of women in the remuneration } \\
\text { committee }\end{array}$ & 0.559 & 0.505 & 7499.773 & 1.107 & 0.268 \\
\hline
\end{tabular}

The regressions reported above were repeated using a dummy variable for female presence in the remuneration committee, instead of the variable 'Percentage of women in the remuneration committee'. For the ordinary least squares analysis with bonus divided by salary as dependent variable, the t-value of this dummy variable is significant at the $5 \%$ level $(\mathrm{t}=-2.972$; significance $=0.003)$. For the ordinary least squares analysis with total variable compensation divided by salary as dependent variable, the $t$-value of this dummy variable is not significant at the $5 \%$ level $(\mathrm{t}=-1.921$; significance $=0.055)$. For the multilevel model analyses, the dummy for female presence is not significant for both dependent variables (respectively: $t=-0.991$; significance $=0.322$; and $\mathrm{t}=-0.059$; significance $=0.953$ ).

In short, the finding of a relationship between a female presence in the remuneration committee and the relative weight of the annual bonus is only robust to the use of the dummy variable in the ordinary least squares analysis. Controlling for firm effects, the dummy variable has no significant relationship with the dependent variables.

To summarize, the null hypothesis is rejected with regard to annual bonus divided by salary, but this finding must be interpreted with caution. In general, the results are in line with psychological theory regarding gender-differences in risk- and inequality-aversion. Especially the findings of Croson and Gneezy (2009) can be helpful in interpreting the results of this study. Firstly, women have been shown to be more risk-averse than men. Since the amount of annual bonuses for executives is generally tied to performance-measures, this form of compensation contains a certain amount of risk, relative to salary. This explains women's preference for salary as opposed to variable compensation in general. Secondly, women have been found to be more inequality-averse than men. Hence, women may tend to reduce compensation-inequalities when possible. This may explain why a female presence in the remuneration committee results in a more equal distribution of compensation across executives (i.e. a higher amount of salary relative to variable compensation).

An opposing argument, based on agency theory, holds that better corporate governance should result in a better alignment of the interests of managers and shareholders. One way to achieve this alignment is to tie executive's pay to firm performance. Because board diversity has been found to be associated with better corporate governance, a female presence in remuneration committees might therefore be expected to lead to a greater emphasis on variable compensation. The findings reported here do not support this argument.

The results of this study form an interesting contribution to the ongoing debate on the determinants of executive compensation. In recent times, agency theory has been the dominant approach in academic research into executive pay. Because the linkage between pay and performance predicted by agency theory is consistently found to be quite weak, most empirical studies of CEO pay left many observers dissatisfied (Main et al., 2008). Taking other theoretical models into account - such as the managerial power theory and tournament models researchers have still not been able to explain a large part of the variation in executive pay (e.g. Lambert et al., 1993). This study shows that the gender composition of the remuneration committee should play a role in the academic debate on top executive's compensation.

Concerning the control variables, the regression reveals an interesting relationship between the executive's gender and the relative weight of variable compensation. In concordance with prior research (e.g. Albanesi \& Olivetti, 2006; Chauvin \& Ash, 1994), it appears that female executives receive a relatively higher part of their compensation in the form of salary. This effect is significant in all of the models described above. It confirms the results of Croson and Gneezy (2009) with respect to gender differences in risk-aversion. 
In addition, the size, industry and performance control variables are statistically significant in the expected direction in all models. However, results for the corporate governance control variables are mixed. For instance, the dummy for remuneration committee independence is insignificant in all models. This result does not support the argument that the relative weight of variable pay is affected by a presence in the remuneration committee of directors who are either employees or in any other way classified as 'linked' to management. Also, the number of remuneration committee members has a positive relation with annual bonus relative to salary, and a negative relation with total variable compensation relative to salary in the ordinary least squares model (but not in the multilevel model). A speculative explanation for this finding may be that compensation in the form of stock options and long-term incentive plans is better suited to align the interests of management with those of shareholders than compensation in the form of annual bonuses. This alignment of interests is one of the objectives of good corporate governance. Since larger boards have been associated with weaker corporate governance, they may tend to place less emphasis on stock-based compensation relative to cash-based compensation.

\subsection{Implications for Management}

In the ongoing academic debate on the determinants of top executive compensation, the effects of gender have not received much attention. Instead, researchers have examined executive pay from the perspectives of agency theory, managerial power theory and tournament models. This paper investigates the role of the gender composition of the remuneration committee. Psychological research related to gender differences in risk- and inequality-aversion predicts that women generally prefer fixed pay to variable pay. On the other hand, corporate governance theory predicts that demographically diverse boards are associated with better corporate governance and therefore with more emphasis on performance-contingent compensation.

Controlling for size, industry, and corporate governance variables, this paper uses simple least squares analysis to regress measures of the relative weight of variable compensation against measures of female presence in the remuneration committee, in a sample of 25806 fiscal year/executive combinations. This regression is repeated in a multilevel model that controls for firm fixed effects in a sample of 9048 fiscal year / executive combinations. The results indicate that a female presence in the remuneration committee is negatively associated with the relative weight of the annual bonus in top executives' compensation contracts.

\subsection{Limitations of the Study}

This study has some limitations. Because of the very large sample size, several possible control variables were excluded due to a lack of data. The models do not control for ethnic diversity of the remuneration committee, or the extent of institutional ownership, both of which may have an effect on the quality of corporate governance and the relationship between fixed and variable pay. If these control variables would have been included, the sample would have been much smaller because the data in the RiskMetrics database are far from complete with regard to these variables.

\subsection{Directions for Future Research}

Future research should build on psychological theory to better investigate the psychological gender-differences that drive the relationships identified in this study. Experimental research settings could be used to link data on compensation contracts with data on the motivations and attitudes of those who determine these compensation contracts. Future research should also focus on gender-differences in preferences for cash-based variable compensation as opposed to stock-based variable compensation. In addition, more recent developments could be examined by extending the sample period in investigating whether there is a crises effect on executive board compensation structure.

\section{References}

Adams, R. B., \& Ferreira, D. (2009). Women in the boardroom and their impact on governance and performance. Journal of Financial Economics, 94(2), 291-309. https://doi.org/10.1016/j.jfineco.2008.10.007

Aggarwal, R. K., \& Samwick, A. A. (1999). The other side of the trade-off: The impact of risk on executive compensation. Journal of Political Economy, 107(1), 65-105. https://doi.org/10.1086/250051

Albanesi, S., \& Olivetti, C. (2006). Gender and Dynamic Agency: Theory and Evidence on the Compensation of Female Top Executives, Macro-economics Working Paper Series WP2006-061. Boston, MA: Boston University - Department of Economics.

Baxter, J., \& Chua, W. F. (2003). Alternative management accounting research: Whence and whither. Accounting, Organizations and Society, 28(2-3), 97-126. https://doi.org/10.1016/S0361-3682(02)00022-3 
Bell, L. A. (2005). Women-led Firms and the Gender Gap in Top Executive Jobs (Discussion Paper No.1689). Bonn, Germany: Institute for the Study of Labor.

Carter, D. A., Simkins, B. J., \& Simpson, W. G. (2003). Corporate governance, board diversity and firm value. The Financial Review, 38, 33-53. https://doi.org/10.1111/1540-6288.00034

Chauvin, K. W., \& Ash, R. A. (1994). Gender earnings differentials in total pay, base pay and contingent pay. Industrial and Labour Relations Review, 47(4), 634-649. https://doi.org/10.1177/001979399404700408

Croson, R., \& Gneezy U. (2009). Gender differences in preferences. Journal of Economic Literature, 47(2), 448-474. https://doi.org/10.1257/jel.47.2.448

Daily, C. M., Johnson, J. L., Ellstrand, A. E., \& Dalton, D. R. (1998). Compensation committee composition as a determinant of CEO compensation. The Academy of Management Journal, 41(2), 209-220. https://doi.org/10.2307/257103

Dohmen, T., \& Falk, A. (2011). Performance pay and multidimensional sorting: Productivity, preferences, and gender. The American Economic Review, 101(2), 556-590. https://doi.org/10.1257/aer.101.2.556

Eagly, A. H., \& Johnson, B. T. (1990). Gender and leadership style: A meta-analysis. Psychological Bulletin, 108(2), 233-256. https://doi.org/10.1037/0033-2909.108.2.233

Eisenhardt, K. M. (1989). Agency theory: An assessment and review. The Academy of Management Review, 14(1), 57-74.

Gomez-Mejia, L. R., \& Wiseman, R. M. (1997). Reframing executive compensation: An assessment and outlook. Journal of Management, 23(3), 291-374. https://doi.org/10.1016/s0149-2063(97)90035-0

Holström, B. (1979). Moral hazard and observability. The Bell Journal of Economics, 10(1), 74-91. https://doi.org/10.2307/3003320

Itnner, C. D., Larcker, D. F., \& Rajan, M. V. (1997). The choice of performance measures in annual bonus contracts. The Accounting Review, 72(2), 231-255.

Jensen, M. C., \& Meckling, W. (1976). Theory of the firm: Managerial behavior, agency costs, and ownership structure. Journal of Financial Economics, 3(4), 305-360. https://doi.org/10.1016/0304-405X(76)90026-X

Jensen, M. C., \& Murphy, K. J. (1990). Performance pay and top management incentives. Journal of Political Economy, 98(2), 225-264. https://doi.org/10.1086/261677

Lambert, R. A., Larcker, D. F., \& Weigelt, K. (1993). The structure of organizational incentives. Administrative Science Quarterly, 38(3), 438-461. https://doi.org/10.2307/2393375

Larcker, D. F., Richardson, S. A., \& Tuna, A. I. (2007). Corporate governance, accounting outcomes, and organizational performance. The Accounting Review, 82(4), 963-1031.

https://doi.org/10.2308/accr.2007.82.4.963

Lazear, E. P. (1998). Personnel economics. Cambridge, MA: The MIT Press.

Luft, J. L., \& Shields, M. D. (2003). Mapping management accounting: Graphics and guidelines for theory-consistent empirical research. Accounting, Organizations and Society, 28(2-3), 169-249. https://doi.org/10.1016/S0361-3682(02)00026-0

Main, B. G. M., Jackson, C. M., Pymm, J., \& Wright, V. M. (2008). The remuneration committee and strategic human resource management. Corporate Governance: An International Review, 16(3), 225-237. https://doi.org/10.1111/j.1467-8683.2008.00682.x

Mills, A. J., \& Simmons, A. M. (1995). Reading organization theory. Toronto, Canada: Garamond Press.

Newman, H. A., \& Mozes, H. A. (1999). Does the composition of the compensation committee influence CEO compensation practices? Financial Management, 28(3), 41-53. https://doi.org/10.2307/3666182

Nielsen, S., \& Huse, M. (2010). The contribution of women on boards of directors: Going beyond the surface. Corporate Governance: An International Review, 18(2), 136-148. https://doi.org/10.1111/j.1467-8683.2010.00784.x

Prendergast, C. (1999). The provision of incentives in firms. Journal of Economic Literature, 37(1), 7-63. https://doi.org/10.1257/jel.37.1.7

Robin, D., \& Babin, L. (1997). Making sense of the research on gender and ethics in business: A critical analysis and extension. Business Ethics Quarterly, 7(4), 61-90. https://doi.org/10.2307/3857209 
Rose, C. (2007). Does female board representation influence form performance? The Danish evidence. Corporate Governance: An International Review, 15(2), 404-413. https://doi.org/10.1111/j.1467-8683.2007.00570.x

Rosen, S. (1986). Prizes and incentives in elimination tournaments. American Economic Review, 76(4), 701-715.

Smith, A. (1904). An Inquiry into the Nature and Causes of the Wealth of Nations. London, England: Methuen and Co.

Taussig, F. W., \& Baker, W. S. (1925). American corporations and their executives: A statistical inquiry. The Quarterly Journal of Economics, 40(1), 1-51. https://doi.org/10.2307/1885814

Terjesen, S., Sealy, R., \& Singh, V. (2009). Women directors on corporate boards: A review and research agenda. Corporate Governance: An International Review, 17(3), 320-337. https://doi.org/10.1111/j.1467-8683.2009.00742.x

Tosi, H. L., Werner, S., Katz, J. P., \& Gomez-Mejia, L. R. (2000). How much does performance matter? A meta-analysis of CEO pay studies. Journal of Management, 26(2), 301-339. https://doi.org/10.1177/014920630002600207

Young, M. N., \& Buchholtz, A. K. (2002). Firm performance and CEO pay: Relational demography as a moderator. Journal of Managerial Issues, 14(3), 296-313.

\section{Copyrights}

Copyright for this article is retained by the author(s), with first publication rights granted to the journal.

This is an open-access article distributed under the terms and conditions of the Creative Commons Attribution license (http://creativecommons.org/licenses/by/4.0/). 